ORIGINAL ARTICLE

\title{
Gonadotropin inhibitory hormone downregulates steroid hormone secretion and genes expressions in duck granulosa cells
}

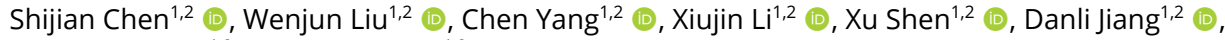 \\ Yunmao Huang ${ }^{1,2 \star}$ (D), Yunbo Tian ${ }^{1,2 \star}$ (D) \\ 'Zhongkai University of Agriculture and Engineering, Guangdong Guangzhou, China \\ ${ }^{2}$ Guangdong Province Key Laboratory of Waterfowl Healthy Breeding, Guangdong Guangzhou, China
}

How to cite: Chen S, Liu W, Yang C, Li X, Shen X, Jiang D, Huang Y, Tian Y. Gonadotropin inhibitory hormone downregulates steroid hormone secretion and genes expressions in duck granulosa cells. Anim Reprod. 2021;18(2):e20210036. https://doi.org/10.1590/1984-3143-AR2021-0036

\begin{abstract}
The mechanisms by which GnIH regulates the steroid synthesis pathway in duck granulosa cells remain poorly understood. In this study, we measured steroid hormone secretion by ELISA and reproductionassociated gene expression by quantitative real-time Polymerase Chain Reaction (qPCR) in duck granulosa cells treated with different concentrations of $\mathrm{GnIH}(0,0.1,1,10$, and $100 \mathrm{ng} / \mathrm{mL})$ for $24 \mathrm{~h}$. The genomewide expression profiles of $\mathrm{GnlH}$-treated cells $(0$ and $10 \mathrm{ng} / \mathrm{mL}$ ) were evaluated by high-throughput RNA sequencing. Compared with untreated cells, the secretion of the steroid hormones E2, E1, P4, and T was downregulated, with that of $\mathrm{E} 1$ and $\mathrm{P} 4$ reaching statistical significance $(P<0.05)$; in contrast, the secretion of ACV and INH was significantly upregulated $(P<0.05)$ after treatment with 10 and $100 \mathrm{ng} / \mathrm{mL} \mathrm{GnlH}$. The expression of encoding steroidogenic proteins and enzymes genes (STAR, CYP11A1, CYP17A1, CYP19A1, and $3-\beta-H S D)$ and encoding gonadotropin receptors genes $(F S H R, L H R)$ were significantly declined $(P<0.05)$ in the 10 and $100 \mathrm{ng} / \mathrm{mL} \mathrm{GnIH}$ treatments. Transcriptome sequencing identified 348 differentially expressed genes (DEGs), including 253 upregulated and 95 downregulated genes. The DEGs were mainly involved in cell growth and death, immune response, and steroid biosynthesis pathways. We identified four novel DEGs (MROH5, LOC113840576, SDR42E1, and LOC113841457) with key roles in the regulation of steroid hormone biosynthesis. Our study revealed changes in gonadal steroid hormone secretion and steroid biosynthesis pathway-related gene expression in duck granulosa cells under the inhibitory effect of $\mathrm{GnIH}$. These data contribute to our understanding of the molecular and genetic mechanisms underlying reproduction in ducks.
\end{abstract}

Keywords: Gonadotropin-inhibitory hormone $(\mathrm{Gn} / \mathrm{H})$, steroid synthesis, gene expression, reproduction, granulosa cell.

\section{Introduction}

In 2000, a hypothalamic neuropeptide isolated from the brain of Japanese quail, named gonadotropin inhibitory hormone $(\mathrm{GnIH})$, was shown to inhibit the release of a gonadotropin (Tsutsui et al., 2000). GnIH plays an essential role in regulating animal reproduction and has inhibitory effects on reproductive regulation and gonadotropin expression. It can directly or indirectly inhibit the activity of gonadotropin-releasing hormone GnRH-expressing neurons in the hypothalamus to regulate the secretion and synthesis of pituitary gonadotropin (Ubuka et al., 2012). The addition of GnIH to cultures of diced pituitary glands from adult cockerels results in a significant decrease in the

*Corresponding author: huangyunmao@zhku.edu.cn, tyunbo@126.com

Received: April 14, 2021. Accepted: June 07, 2021.

Financial support: This research was supported by the National Key Technologies R\&D Program of China (2016YFD0500510 and 2018 YFF0128200) and the Pearl River S\&T Nova Program of Guangzhou (201906010040).

Conflicts of Interest Statement: The authors declare that they have no known competing financial interests or personal relationships that could have appeared to influence the work reported in this paper. 
secretion levels of follicle-stimulating hormone (FSH) and luteinizing hormone (LH) (Ciccone et al., 2004).

GPR147 and GPR74 have been shown to act as G protein-coupled receptors for GnIH in gonadotropic cells and gonads (Yin et al., 2005). Previous studies have indicated that $\mathrm{GnIH}$ and its receptors are also expressed in follicle granulosa cells (Ubuka et al., 2013), suggesting that GnIH may have an autocrine/paracrine regulatory role in gonadal steroid production and germ cell maturation (Bentley et al., 2008; Ubuka et al., 2016). Under the stimulation of $\mathrm{FSH}$ and $\mathrm{LH}$, granulosa cells synthesize estradiol and progesterone to regulate follicle maturation and ovulation. Previous studies have shown that GnIH reduces ovarian activity, inhibits follicular development, and also reduces the expression of the proliferation-related proteins ERK1/2, cyclin-B1, and PCNA in porcine ovarian granulosa cells (Singh et al., 2011a; Li et al., 2013). This suggests that GnlH not only acts on the hypothalamic-pituitary-gonadal (HPG) axis but also regulates ovarian development and function (Bentley et al., 2010). However, few studies have examined the regulatory effects of $\mathrm{GnIH}$ on steroid hormone secretion and related pathways of granular cells as well as their underlying mechanisms.

The aim of our study was to investigate (1) changes in the secretion of important steroid hormones and the expression of related genes in duck granulosa cells under treatment with different concentrations of $\mathrm{GnIH}(0,0.1,1,10$, and $100 \mathrm{ng} / \mathrm{mL}$, duck species $\mathrm{GnIH}$ : SIKPIANMPLRF) over $24 \mathrm{~h}$ and (2) novel genes that regulate the steroid synthesis pathway by RNA-seq in the 0 and $10 \mathrm{ng} / \mathrm{mL} \mathrm{GnlH}$ treatments.

\section{Methods}

\section{Isolation and culture of granulosa cells}

Small yellow follicles (SYFs, 5-12 mm in diameter) were collected immediately from the ovaries of ten laying ducks and placed in ice-cold phosphate-buffered saline (PBS, Gibco, Grand Island NY, USA) with $100 \mathrm{U} / \mathrm{mL}$ of penicillin or streptomycin (Gibco, USA). The granulosa cells were carefully separated from SYFs and treated with collagenase II (Biosharp, China) at $37{ }^{\circ} \mathrm{C}$ for 20 min. An equal volume of M199 medium (M199, Gibco, USA) containing fetal bovine serum (FBS, Gibco, South America) was added to stop the digestion, and the cell suspension was filtered through a 70- $\mu \mathrm{m}$ cell strainer (JET BIOFIL). After centrifuging the filtrate at 1,000 rpm for $5 \mathrm{~min}$ at $4{ }^{\circ} \mathrm{C}$, it was resuspended in M199 medium containing FBS and $100 \mathrm{U} / \mathrm{mL}$ of penicillin or streptomycin. Cell viability and concentration were assessed by an automatic cell counter (BodBoge, Shenzhen, China). A total of $10 \mu \mathrm{L}$ of the cell suspension was introduced onto the counting slide, and the live cell count and percentage were automatically measured. Next, the cells were plated at a density of $1 \times 10^{6} / \mathrm{mL}$ cells in 6-well plates (Corning Costar) and cultured with $5 \% \mathrm{CO}_{2}$ at $39{ }^{\circ} \mathrm{C}$. When cells had reached confluence, the medium was replaced with M199 containing different concentrations of $\mathrm{GnIH}(0,0.1,1,10$, and $100 \mathrm{ng} / \mathrm{mL})$ for $24 \mathrm{~h}$. The cells were also plated at a density of $5 \times 10^{7}$ cells in $10-\mathrm{cm}$ diameter Petri dishes (Corning Costar, NY, USA) and cultured with $5 \% \mathrm{CO}_{2}$ at $39{ }^{\circ} \mathrm{C}$. The cells were treated with different concentrations of $\mathrm{GnIH}(0$ and $10 \mathrm{ng} / \mathrm{mL}$ ) for $24 \mathrm{~h}$ and collected for transcriptome sequencing.

The culture medium collected from the 6-well plates was used to measure steroid hormone $(E 1, T, E 2, P 4, A C V$, and INH) secretion levels by sandwich method ELISA, and the cells were used to measure the expression levels of eight key genes (STAR, CYP11A1, CYP17A1, CYP19A1, 3- $\beta$-HSD, $F S H R, L H R$, and $G n I H R)$ by qPCR. 


\section{RNA extraction, library preparation, and RNA sequencing}

Total RNA was extracted from granulosa cells using Trizol reagent (Invitrogen, Carlsbad, CA, USA) following the manufacturer's recommendations. RNA-seq transcriptome libraries were prepared with the TruSeq RNA Sample Preparation Kit from

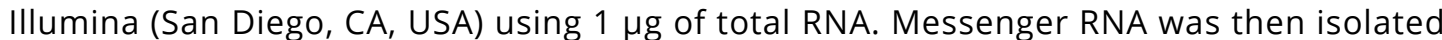
by polyA selection using oligo (dT) beads and fragmented using fragmentation buffer. cDNA synthesis, end-repair, A-base addition, and ligation of the Illumina-indexed adaptors were performed per the manufacturer's protocol. Libraries were then sizeselected for cDNA target fragments of 200-300 bp on 2\% Low Range Ultra Agarose followed by 15 cycles of PCR amplification using Phusion DNA polymerase (M0530L, NEB). The PCR reaction mixture $(50 \mu \mathrm{L})$ contained $25 \mu \mathrm{L}$ of HIFI Amplification Mix, $2 \mu \mathrm{L}$ PCR Primer Mix, and $23 \mu \mathrm{L}$ target fragments. The reaction procedure was as follows: $98^{\circ} \mathrm{C}$ for $45 \mathrm{~s}$; followed by 15 cycles of $98{ }^{\circ} \mathrm{C}$ for $15 \mathrm{~s}, 60^{\circ} \mathrm{C}$ for $30 \mathrm{~s}$ and $72{ }^{\circ} \mathrm{C}$ for $30 \mathrm{~s} ; 72{ }^{\circ} \mathrm{C}$ for 5 min. Paired-end ( $2 \times 151$ bp read length) libraries were sequenced using a Truseq SBS Kit (300 cycles, Illumina).

\section{Read quality control and mapping}

The raw paired-end reads were trimmed and quality controlled by Trimmomatic (Bolger et al., 2014) with the following parameters: ILLUMINACLIP: TruSeq2-PE.fa:2:30:10 LEADING:3 TRAILING:3 SLIDINGWINDOW:4:15 MINLEN:75. The clean reads were then aligned to the reference genome (Huang et al., 2013) via HIAST2 (version 2.0.5) (Kim et al., 2015a) software using the default settings.

\section{Analysis and annotation of DEGs}

SAM files were sorted using the sort procedure of SAMtools (version 1.7) (Li et al., 2009). Using the program htseq-count (version 0.11.2) (Anders et al., 2015), the sorted SAM files were used to generate read counts expressed per gene per library to calculate the expression level of each transcript using fragments per kilobase of exon per million mapped reads (FPKM) (Roberts et al., 2011), as well as conduct DEGs analysis using functions within the R package NOIseq (version 2.22.1) (Tarazona et al., 2011). Genes were considered differentially expressed if the probability was $\geq 0.8$ and fold-change was $\geq 1.5$. GO functional enrichment analysis was performed using the $\mathrm{R}$ package GOSeq (version 1.10.0) (Young et al., 2010) and topGO (version 2.10.0), and Kyoto Encyclopedia of Genes and Genomes (KEGG) pathway analysis was performed using KOBAS (version 2.0.12) (Xie et al., 2011). DEGs were considered significantly enriched in GO terms and metabolic pathways when their Bonferroni-corrected $P$-value was $\leq 0.05$.

\section{qPCR analysis}

The design of the primer sequences was based on Primer 5.0 software and synthesized by Sangon Biotech Co., Ltd. (Shanghai, China) (Table 1). qPCR was performed using an ABI7500 Real-Time PCR system (Applied Biosystems, Foster City, CA, USA). Reactions were performed using the SYBR Prime Script RT-PCR Kit (Takara Bio Inc, DRR041A, Japan) per the manufacturer's instructions. Melt curve analysis and efficiency tests for primers were carried out to ensure primers were amplified as a single product with $90-110 \%$ efficiency. The qPCR reaction mixture $(20 \mu \mathrm{L})$ contained $1 \mu \mathrm{L}$ of sample CDNA, $0.2 \mu \mathrm{M}$ forward and reverse primers, $8.6 \mu \mathrm{L}$ of DNase-free water, and $10 \mu \mathrm{L}$ of SYBR Premix Dimer Eraser. The reaction procedure was as follows: $95^{\circ} \mathrm{C}$ for $30 \mathrm{~s}$, followed by 40 cycles of $94{ }^{\circ} \mathrm{C}$ for $5 \mathrm{~s}$ and $60^{\circ} \mathrm{C}$ for $30 \mathrm{~s}$. The fold-changes in gene expression levels were calculated using the $2^{-\Delta \Delta C T}$ method (Livak and Schmittgen, 2001). The glyceraldehyde-3-phosphate dehydrogenase gene (GAPDH) was used as the reference gene. 
Table 1. $\mathrm{qPCR}$ primer sequences.

\begin{tabular}{|c|c|c|}
\hline Gene & Primer sequence (5'-3') & $\begin{array}{c}\text { NCBI reference } \\
\text { sequence }\end{array}$ \\
\hline \multirow{2}{*}{ GAPDH } & F:GCTGATGCTCCCATGTTCGTGAT & \multirow{2}{*}{ XM_027449739.1 } \\
\hline & R:GTGGTGCAAGAGGCATTGCTGAC & \\
\hline \multirow{2}{*}{ FSHR } & F: AGTGTTGAATGTACTCGCCT & \multirow{2}{*}{ XM_021267212.2 } \\
\hline & R: TGTCTGTTCTGTAAATCTGG & \\
\hline \multirow{2}{*}{$L H R$} & F: GCTCTGTGATAACTTGCGTA & \multirow{2}{*}{ EU049613.1 } \\
\hline & R: TGAGGTTTCTGTTGTCCTTC & \\
\hline \multirow{2}{*}{ STAR } & F: CTGCCATCTCCTACCGCCAC & \multirow{2}{*}{ XM_027443533.1 } \\
\hline & R: CTGCTCCACCACCACCTCCA & \\
\hline \multirow{2}{*}{ CYP11A1 } & F: ACAGGGAGAAGTTGGGTGTC & \multirow{2}{*}{ KY463321.1 } \\
\hline & R: GTAGGGCTTGTTGCGGTAGT & \\
\hline \multirow{2}{*}{ CYP17A1 } & F: GTCGCCCTGGAGAAGATCAT & \multirow{2}{*}{ NM_001001901.2 } \\
\hline & R: TCGGTAGGAGGAGTTGAAGC & \\
\hline \multirow{2}{*}{$3-\beta-H S D$} & F: AGAAGTGACAGGCCCAAACT & \multirow{2}{*}{ KC310447.1 } \\
\hline & R: ACATGGATCTCAGGGCACAA & \\
\hline \multirow{2}{*}{ CYP19A1 } & F: GGATGGGAGTAGGTAATGCC & \multirow{2}{*}{ KY762997.1 } \\
\hline & R: ACAAGACCAGGACCAGACAG & \\
\hline \multirow{2}{*}{ GnIHR } & F: CATCCTGGTGTGCTTCATCG & \multirow{2}{*}{ KC514473.1 } \\
\hline & R: ACATGGTGTTGTCAAAGGGC & \\
\hline
\end{tabular}

\section{Statistical analysis}

All results were presented as the means \pm standard error of the mean (SEM) from at least three independent experiments, each one performed in triplicate. Results were analyzed using one-way ANOVA and multiple comparisons by GraphPad Prism 7 (GraphPad Software, La Jolla, ( A, USA). The threshold for significance was $P<0.05$.

\section{Ethics statement}

All experimental procedures in this study were performed in accordance with the Regulations of the Administration of Affairs Concerning Experimental Animals (State Science and Technology Commission in China, 1988) and EU Directive 2010/63/EU on the use of animals for research. All animal experiments were approved by the Animal Care and Use Committee of Zhongkai University of Agriculture and Engineering (Permit Number: 2020-014).

\section{Results}

\section{GnIH treatment downregulated steroid hormone secretion and gene expression in granulosa cells}

We treated duck granulosa cells with different concentrations of $\mathrm{GnIH}(0,0.1,1,10$, and $100 \mathrm{ng} / \mathrm{mL}$ ) for $24 \mathrm{~h}$ and then measured the levels of secreted P4, E1, E2, T, ACV, and INH in the culture medium. The levels of E1 and P4 secretion were lower $(P<0.05)$ under high $\mathrm{GnlH}$ concentrations (10 and $100 \mathrm{ng} / \mathrm{mL}$ ) than in the control group (0 $\mathrm{ng} / \mathrm{mL} \mathrm{GnlH})$ (Figure 1). Treatment with higher GnIH concentrations also inhibited the amount of E2 and T secreted by the granulosa cells; however, treatment with $10 \mathrm{ng} / \mathrm{mL} \mathrm{GnlH}$ had no significant effect $(P>0.05)$. Compared with the control group $(0 \mathrm{ng} / \mathrm{mL} \mathrm{GnlH})$, the levels of secreted P4 and T were significantly reduced $(P<0.05)$ in the $1 \mathrm{ng} / \mathrm{mL} \mathrm{GnIH}$ treatment; the levels of secreted INH and ACV were significantly increased $(P<0.05)$ in the 10 and $100 \mathrm{ng} / \mathrm{mL}$ GnlH treatments. 

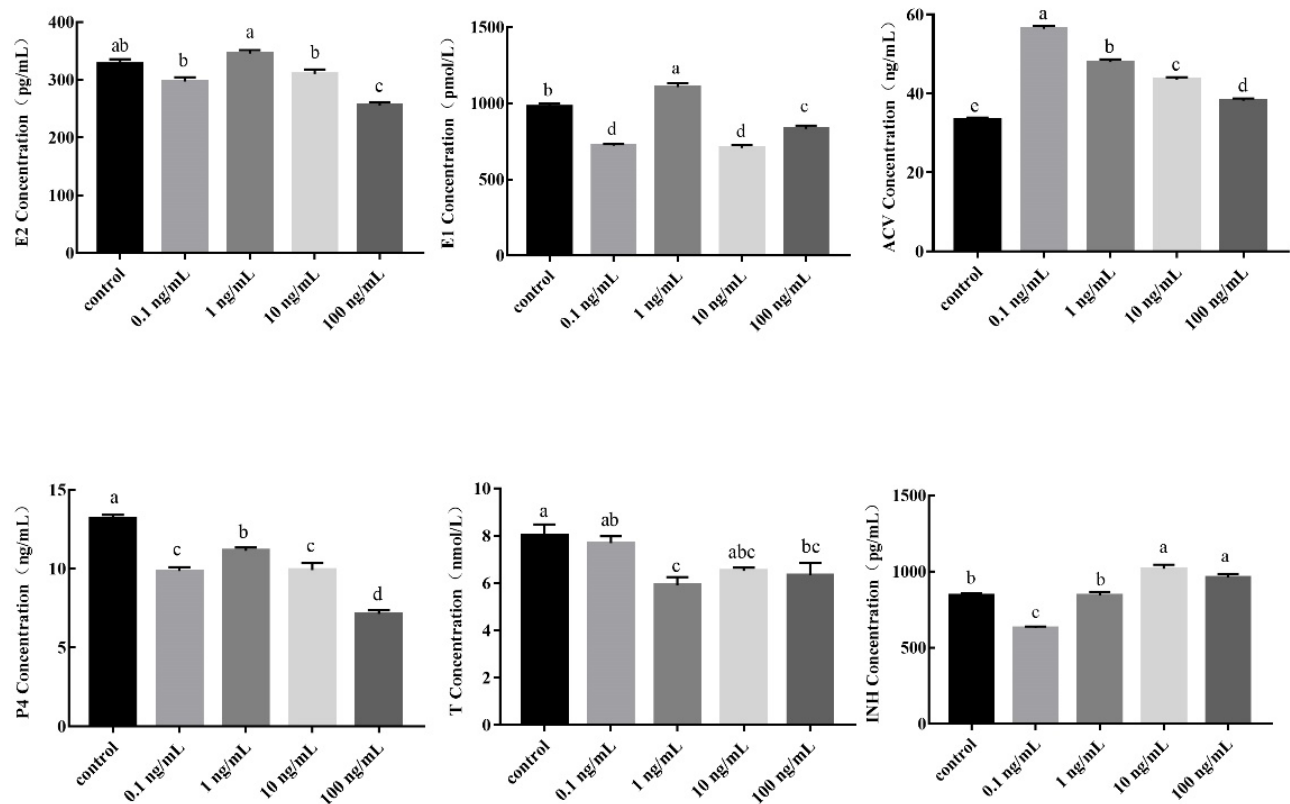

Figure 1. Effect of GnIH treatment on E2, E1, P4, T, ACV, and INH secretion levels. Values were expressed as means \pm SEM. Different lowercase letters indicate significant difference $(P<0.05)$; The inclusion of the same lowercase letters indicate no significant difference $(P>0.05)$.

qPCR was performed to validate reproduction-associated gene expression in duck granulosa cells treated with different concentrations of $\mathrm{GnIH}(0,0.1,1,10$, and $100 \mathrm{ng} / \mathrm{mL})$. The expression of STAR, 3- $\beta-H S D, C Y P 11 A 1, C Y P 17 A 1, C Y P 19 A 1, F S H R$, LHR, and GnIHR was downregulated in the 0.1 and $1 \mathrm{ng} / \mathrm{mL} \mathrm{GnIH} \mathrm{treatment} \mathrm{groups} \mathrm{compared} \mathrm{with} \mathrm{the} \mathrm{control}$ group (0 $\mathrm{ng} / \mathrm{mL} \mathrm{GnlH}$ ) (Figure 2); however, only the expression of CYP11A1 reached statistical significance $(P<0.05)$. The mRNA expression levels of these genes were all significantly downregulated $(P<0.05)$ in cells treated with higher $\mathrm{GnIH}$ concentrations $(10$ and $100 \mathrm{ng} / \mathrm{mL}$ ) relative to cells in the control group $(0 \mathrm{ng} / \mathrm{mL} \mathrm{GnIH})$.

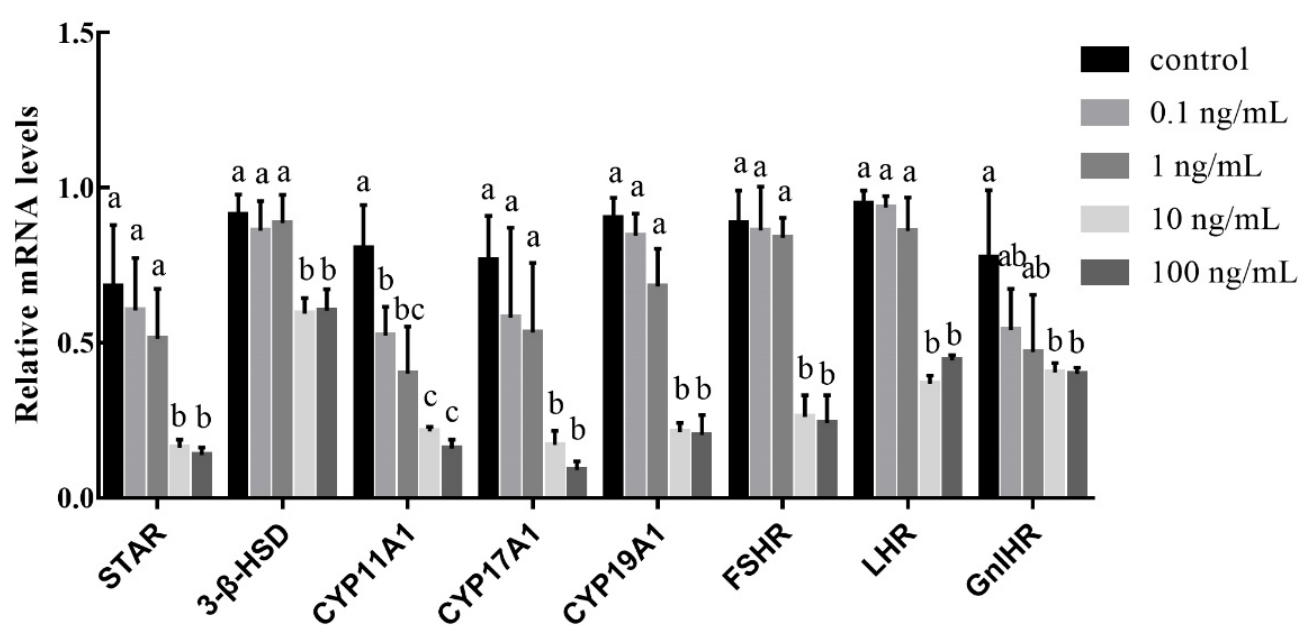

Figure 2. Effect of GnlH treatment on the expression of reproduction related genes. Gene expression was determined by qPCR. The results were normalized based on the GAPDH housekeeping gene. All values were expressed as the mean \pm SEM. Different lowercase letters indicate significant difference $(P<0.05)$; The inclusion of the same lowercase letters indicate no significant difference $(P>0.05)$. 


\section{RNA sequencing}

Granulosa cells treated with different concentrations of $\mathrm{GnIH}(0$ and $10 \mathrm{ng} / \mathrm{mL})$ for 24 h were used for high-throughput RNA sequencing, and there were 3 replicates for each treatment. We obtained $36.87 \mathrm{G}$ of clean bases for 6 samples. Quality evaluation of the raw sequencing data showed that the Q20 ratio of clean reads for all samples exceeded 97\%, and the genomic alignment rate was over $77 \%$ (Table 2). Principal component analysis (PCA) showed that the gene expression patterns in the $10 \mathrm{ng} / \mathrm{mL}$ GnIH treatment group were markedly different from those of the control group ( $0 \mathrm{ng} / \mathrm{mL} \mathrm{GnlH}$ ) (Figure 3).

Table 2. Clean reads statistics.

\begin{tabular}{cccccc} 
Sample & $\begin{array}{c}\text { Total Clean } \\
\text { Reads }\end{array}$ & $\begin{array}{c}\text { Total Mapping } \\
\text { Ratio }\end{array}$ & $\begin{array}{c}\text { Uniquely Mapping } \\
\text { Ratio }\end{array}$ & Q20 (\%) & Q30 (\%) \\
\hline S1-1 & 52615692 & $78.21 \%$ & $71.62 \%$ & 98.24 & 94.26 \\
\hline S1-2 & 50247302 & $78.49 \%$ & $72.07 \%$ & 98.03 & 93.71 \\
\hline S1-3 & 43186154 & $80.51 \%$ & $74.07 \%$ & 98.13 & 93.93 \\
\hline S2-1 & 36420012 & $77.04 \%$ & $69.58 \%$ & 97.92 & 93.49 \\
\hline S2-2 & 48833142 & $77.71 \%$ & $70.90 \%$ & 97.9 & 93.45 \\
\hline
\end{tabular}

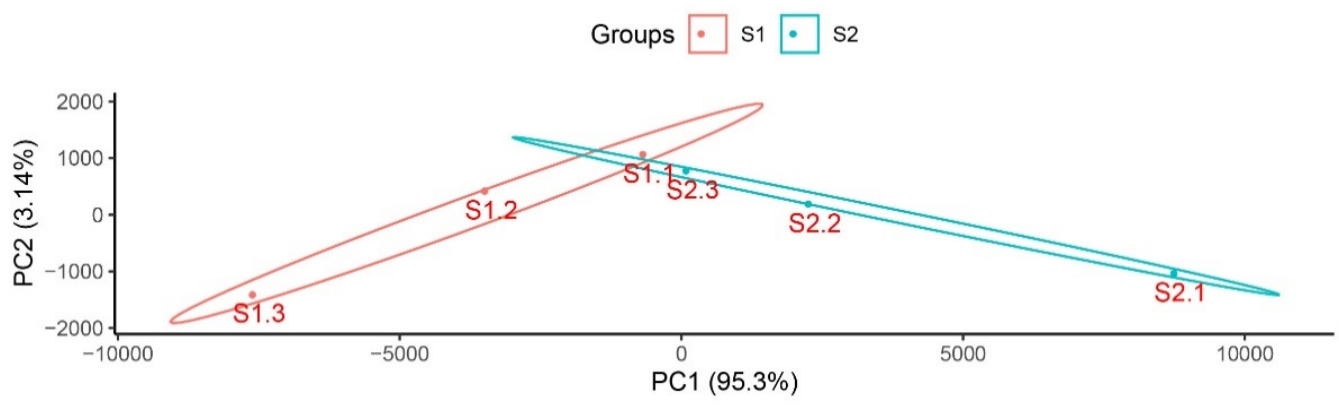

Figure 3. Principal component analysis scatterplot of samples.

\section{DEGs in duck granulosa cells}

A total of 13,794 expressed genes were detected, and 348 DEGs were identified, including 253 upregulated and 95 downregulated genes (Figure 4). The top 10 upregulated genes were LOC101790824, EGR1, FDXR, IL8, SLC15A1, LOC101801765, ATP1B1, CLIC6, LRRC52, and GAS1. The top 10 downregulated genes were HAS2, LAMA3, CDCA7, LOC113842153, ESRRB, ISM1, PRICKLE1, FHOD3, LOC113840872, and ARHGAP20. The ID, description, and summary of the functions of these genes are shown in Table 3 and Table 4.

\section{Gene Ontology (GO) and KEGG analysis}

GO enrichment analysis was performed, and the top 30 significantly enriched GO Terms were examined (Figure 5). The most significantly enriched GO terms were enriched in magnesium ion binding in the molecular function (MF) category, Golgi membrane in the cellular component (CC) category, and mitotic cell cycle in the biological process (BP) category. To explore whether the GO Term functions were dominated by upregulated or downregulated genes, we selected the top 10 significantly enriched GO Terms from BP, CC, and MF. The upregulated genes were mainly enriched in the negative regulation of transcription by RNA polymerase II, and the downregulated genes were mainly enriched in Golgi membrane (Figure 6). According to the KEGG enriched analysis, the DEGs were mainly enriched in 20 key pathways, such as RIG-I-like receptor signalling pathway, Cytokine-cytokine receptor interaction, and Ovarian steroidogenesis (Figure 7). 


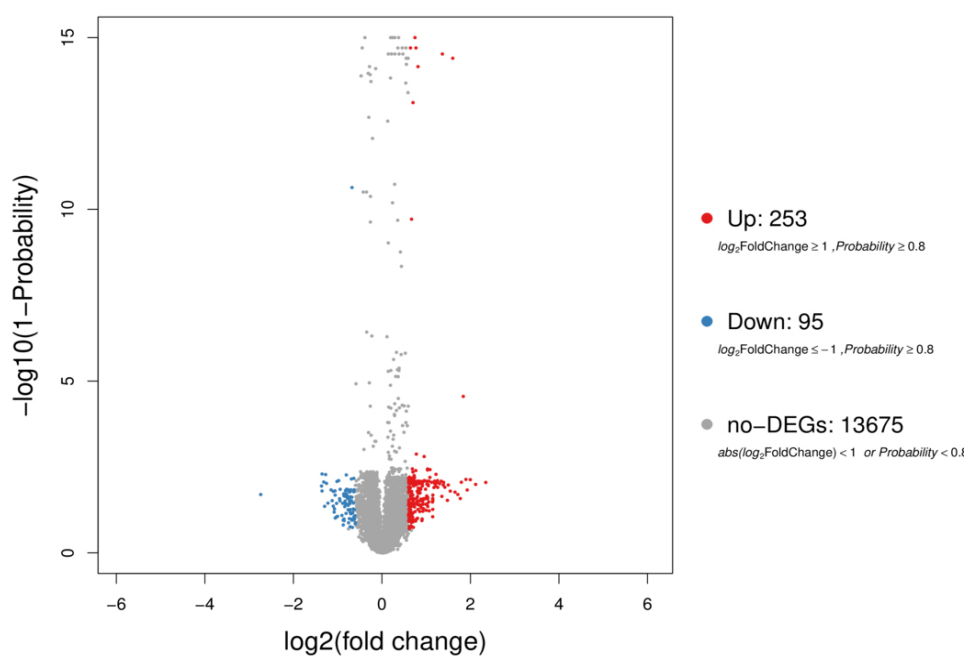

Figure 4. Volcano plot of DEGs in duck granulosa cells. Each dot represents a gene. Red dots indicate upregulated genes, and blue dots indicate downregulated genes. Grey dots indicate genes that were not differentially expressed.

Table 3. The top 10 upregulated genes in granulosa cells.

\begin{tabular}{|c|c|c|}
\hline Gene ID & Gene Name & Description and Summary of Function \\
\hline XM_005026649.4 & LOC101790824 & \\
\hline XM_027468454.1 & EGR1 & A nuclear protein that functions as a transcriptional regulator \\
\hline XM_027471381.1 & FDXR & $\begin{array}{l}\text { Encodes a mitochondrial flavoprotein, initiates electron transport for } \\
\text { cytochrome P450, receives electrons from NADPH }\end{array}$ \\
\hline NM_001310420.1 & IL8 & A major mediator of the inflammatory response \\
\hline NM_001310803.1 & SLC15A1 & $\begin{array}{l}\text { Encodes an intestinal hydrogen peptide cotransporter and is important for } \\
\text { the uptake and digestion of dietary proteins }\end{array}$ \\
\hline XM_027454493.1 & LOC101801765 & \\
\hline NM_001310386.1 & ATP1B1 & $\begin{array}{l}\text { Encodes an integral membrane protein, maintains an essential } \\
\text { electrochemical gradient }\end{array}$ \\
\hline XM_027449142.1 & CLIC6 & Encodes chloride intracellular channel family of proteins \\
\hline XM_027462893.1 & LRRC52 & $\begin{array}{l}\text { An auxiliary protein of the large-conductance, voltage- and calcium- } \\
\text { activated potassium channel }\end{array}$ \\
\hline XM_027446434.1 & GAS1 & $\begin{array}{c}\text { Plays a role in growth suppression, blocks entry into S phase, and prevents } \\
\text { cell cycling }\end{array}$ \\
\hline
\end{tabular}

Table 4. The top 10 downregulated genes in granulosa cells.

\begin{tabular}{lcr} 
Gene ID & Gene Name & Description and Summary of Function \\
XM_005019040.4 & HAS2 & Related to glycosaminoglycan metabolism and metabolism \\
\hline XM_027451936.1 & LAMA3 & Related to nanoparticle effects and cell junction organisation \\
\hline XM_027461168.1 & CDCA7 & Related to validated targets of C-MYC transcriptional activation \\
\hline XM_027448834.1 & LOC113842153 & \\
\hline XM_027459472.1 & ESRRB & Related to the Wnt signalling pathway and Pluripotency \\
\hline XM_027453339.1 & ISM1 & Acts as an angiogenesis inhibitor \\
\hline XM_027457011.1 & PRICKLE1 & Related to Wnt signalling pathways: CDK-mediated phosphorylation and \\
\hline XM_021276453.2 & FHOD3 & removal of Cdc6 \\
\hline XM_027447614.1 & LOC113840872 & Related to binding and actin binding \\
\hline XM_027468631.1 & ARHGAP20 & Related to signaling by GPCRs and Signalling by Rho GTPases
\end{tabular}




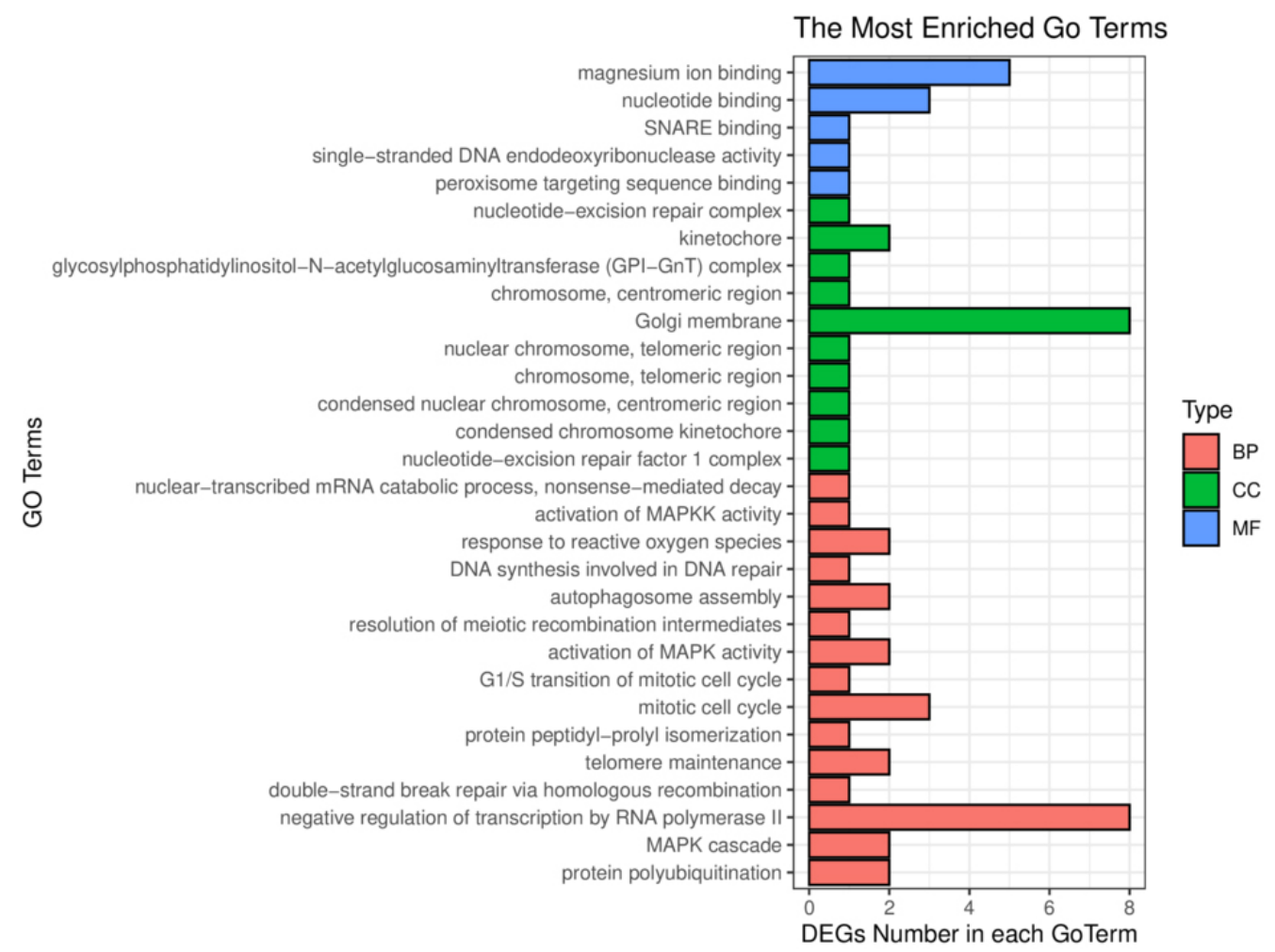

Figure 5. Histogram of Gene Ontology (GO) Terms. Different colors were used to distinguish biological process (BP), cellular component (CC), and molecular function (MF). Blue represents MF, green represents CC, and orange represents BP.

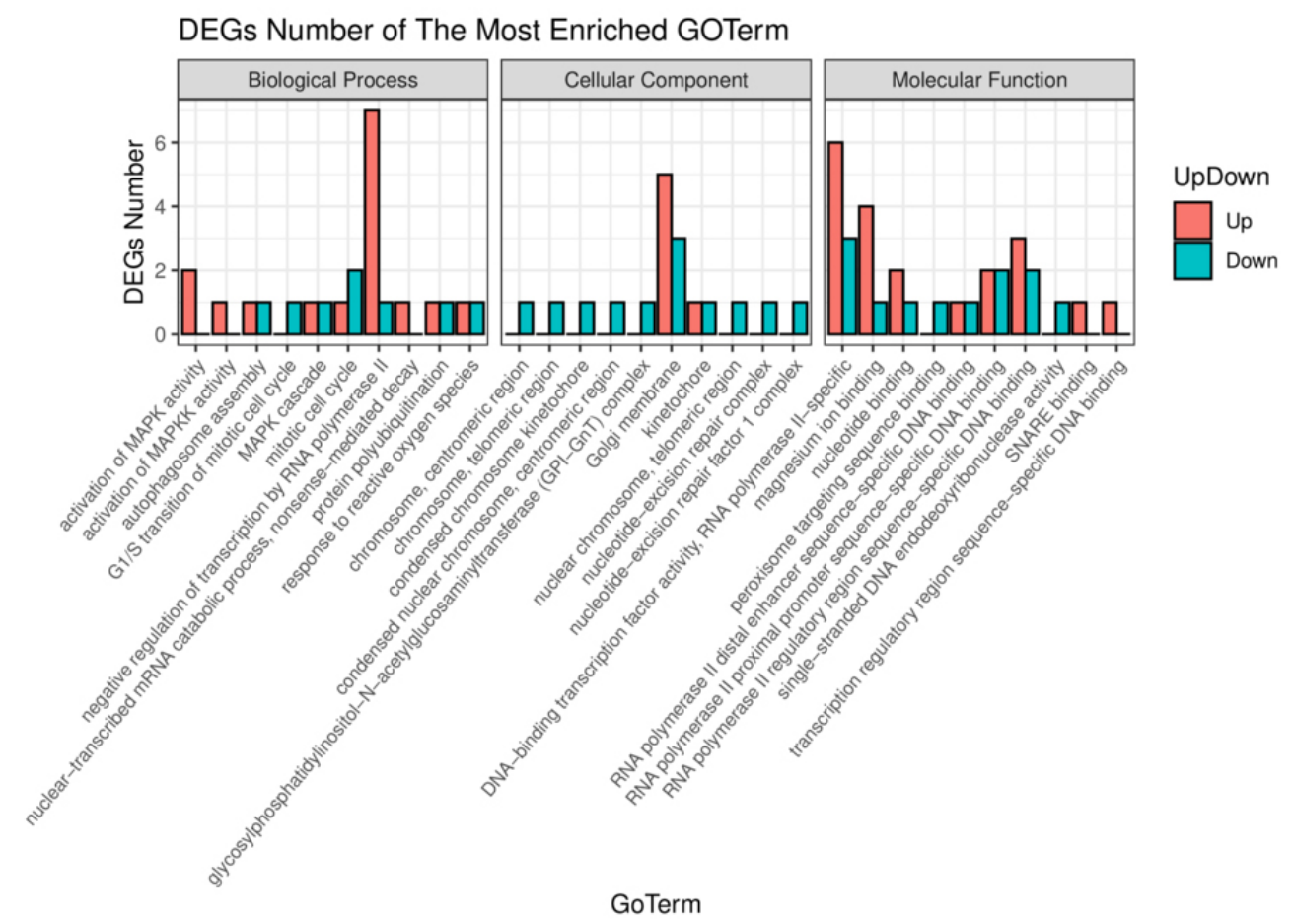

Figure 6. Histogram of enriched GO Terms for DEGs. The orange represents upregulated genes, and green represents downregulated genes. The $x$-axis and $y$-axis indicate the enriched GO Terms and the number of DEGs, respectively. 


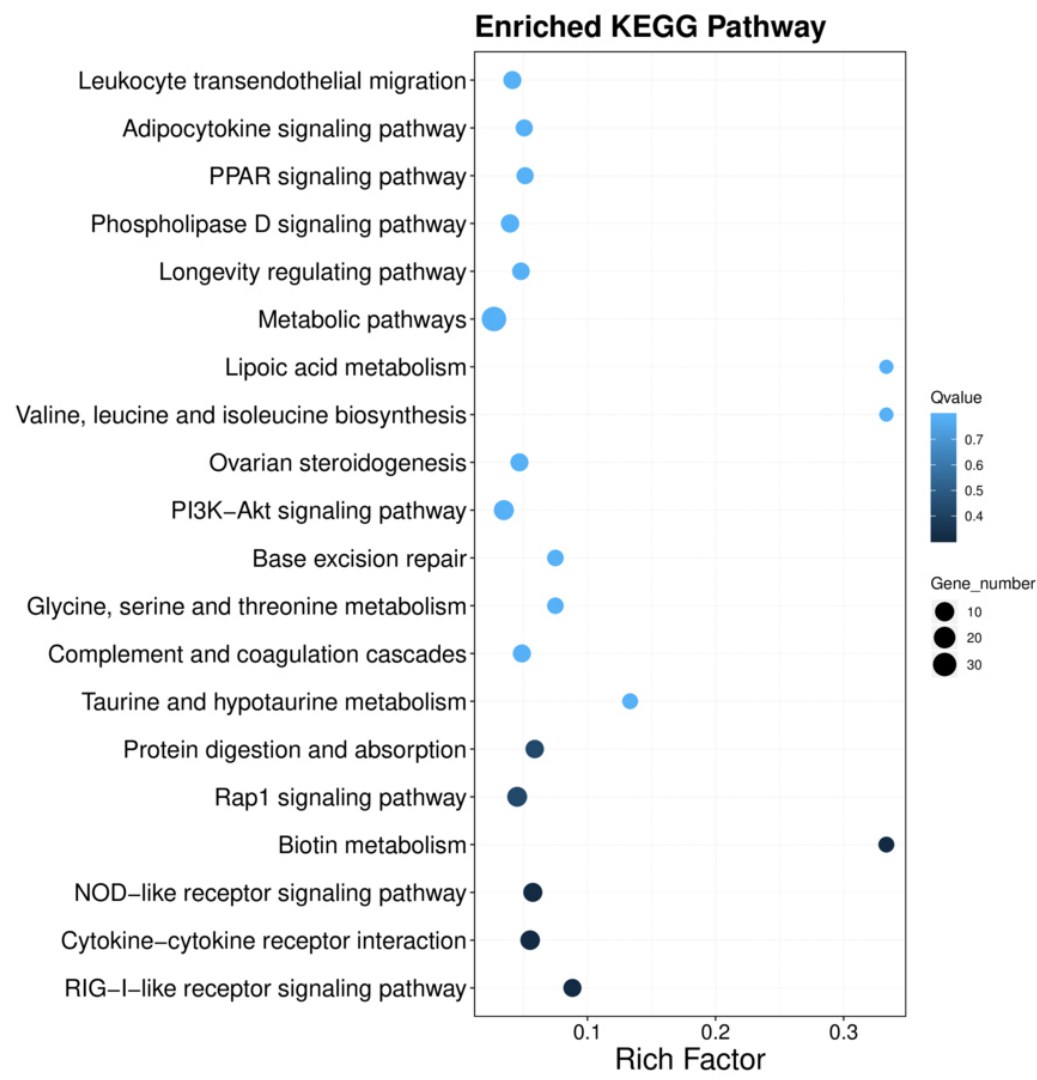

Figure 7. Scatter plot of enriched pathways for DEGs in granulosa cells. The $x$-axis and $y$-axis indicate the rich factor and pathway entry, respectively. The size of the dots indicates the number of significant DEGs; larger dots correspond to a greater number of significant DEGs. Different colored points represent different $Q$-values.

The 15 key DEGs were selected for validation using qPCR, including MAPK pathway-activator genes (FGF19 and RET); cell growth, apoptosis, and cell cycle-related genes (APBB1, GAS1, RRAD, FOXO6, NRG3, TOX3, CDCA7); steroid biosynthetic process-related genes (ESR1, ESRRB); the immune factor IL8; and three other genes (HAS2, FDXR, BMP-6). The verification results for the expression of the DEGs were consistent with those for transcriptome sequencing, indicating that the sequencing results were reliable (Figure 8).

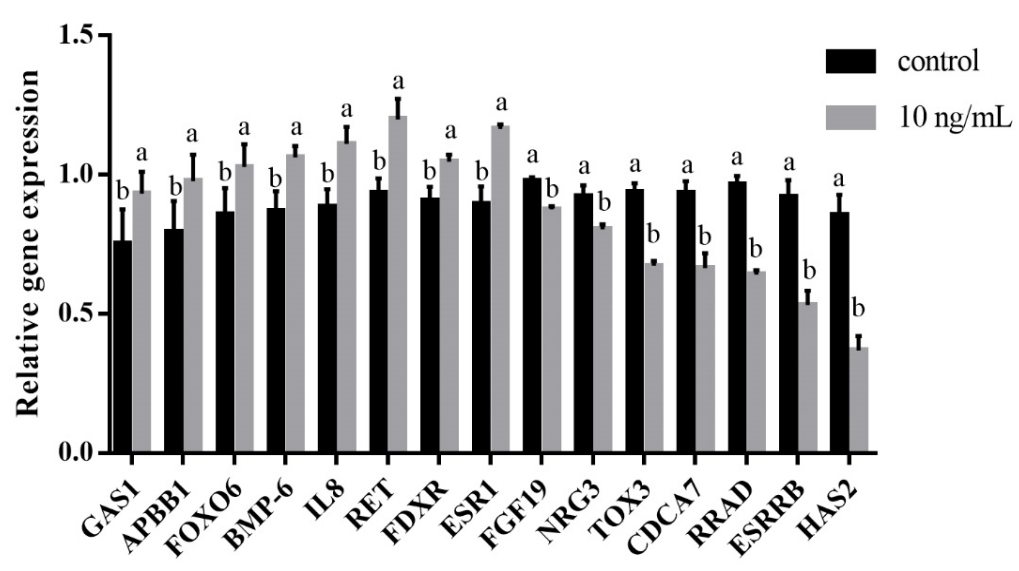

Figure 8. qPCR validation of key DEGs in granulosa cells. Gene expression levels were assessed by qPCR and were presented relative to GAPDH expression. Statistical significance was assessed by $t$-test. Different lowercase letters indicate significant difference $(P<0.05)$. 


\section{Steroidogenesis pathway analysis}

KEGG pathways functional analysis found that six DEGs were enriched in the ovarian steroidogenesis pathway, including MROH5, LOC113840576, SDR42E1, LOC113841457, STAR, and CYP19A1. Four novel genes, MROH5, LOC113840576, SDR42E1, and LOC113841457, were first reported to be related to the ovarian steroidogenesis pathway. We also used these eight DEGs to construct a protein-protein interaction (PPI) network based on the STRING database. Six other genes (EGR1, ESR1, ACER2, CRHR2, CYP3A4, and NR1H4) interacting with DEGs were involved in the pathways of steroid hormone biosynthesis (Figure 9). These genes were found among DEGs and are potential candidate genes for understanding the molecular mechanism underlying reproduction in ducks.

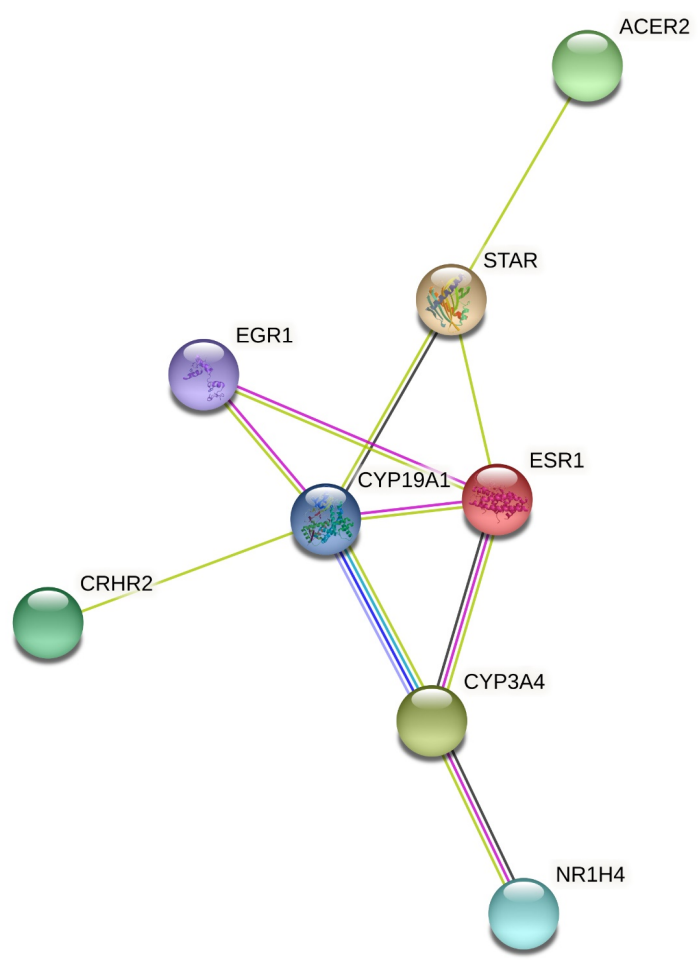

Figure 9. Protein-protein interaction (PPI) network of eight DEGs based on the STRING database.

\section{Discussion}

The recently identified hypothalamic neuropeptide, $\mathrm{GnIH}$, is a key regulator of reproduction. The peripheral injection of GnIH has been shown to inhibit FSH and LH synthesis and release in chicken (Maddineni et al., 2008; McGuire et al., 2011). In mammals, GnIH receptors are distributed in porcine ovarian granulosa cells and reduce the levels of the proliferation-related proteins ERK1/2, cyclin-B1, and PCNA after GnIH treatment (Li et al., 2013). Additionally, GnIH treatment can reduce ovarian activity and inhibit follicular development in mice (Anjum et al., 2012; Singh et al., 2011a). These findings indicate that $\mathrm{GnIH}$ affects the proliferation and development of follicular granulosa cells.

We assessed the expression of STAR, 3- $\beta$-HSD, CYP11A1, CYP17A1, and CYP19A1, the marker genes of steroid synthesis in granulosa cells, after different concentrations of GnIH treatment. These steroid synthesis marker genes play a crucial role in follicular development and the steady state of steroid hormones (Guo et al., 2019). qPCR analyses showed that the expression levels of these genes were downregulated in granulosa cells after GnIH treatment. Previous research has also shown that $\mathrm{GnIH}$ treatment dose-dependently suppressed steroidogenesis by inhibiting the gene expression of STAR and 3- $\beta$-HSD in the ovary of mice (Singh et al., 2011b). 
Moreover, GnIH treatment also decreased the expression of FSHR, LHR, and GnIHR. These findings indicate that $\mathrm{GnIH}$ regulates the proliferation of granulosa cells by reducing the expression of steroid synthesis-associated genes and related receptors. Steroid hormone secretion is essential for the reproduction and development of animals. Steroid synthases catalyze the synthesis of multiple hormones, including T, P4, E2, and E1 (Payne and Hales, 2004). Our results showed that GnIH treatment reduced the secretion level of these steroid hormones. The reduction in the level of P4 may be related to the decreased STAR and CYP11A1 mRNA expression levels (Mosa et al., 2015). Previous studies have also indicated that GnIH treatment reduces the secretion levels of E2 and P4 (Li et al., 2013). Based on these findings, we hypothesized that the downregulated expression of ESRRB and CYP19A1 may inhibit estrogen biosynthesis in granulosa cells, and this in turn results in a low E2 level. The secretion of E2 and P4 has also been confirmed to affect the expression of GnIHR (Maddineni et al., 2008). The lack of E2 also leads to granulosa cell apoptosis, which is consistent with the downregulation of apoptotic gene expression (Shimizu et al., 2005). The secretion level of P4 and the expression of 3- $\beta-H S D$ were both significantly decreased, indicating that GnIH had a direct inhibitory effect on follicular development. In addition, the increase in INH expression may have helped maintain androgen synthesis in theca cells (Johnson, 1993). The upregulation of INH and ACV also had important effects on the proliferation and development of granulosa cells (McNatty et al., 2000; Lovell et al., 2003). In this study, the expression of reproductionassociated genes was downregulated, which was consistent with the pattern of steroid hormone secretion. These results indicate that $\mathrm{GnIH}$ regulates the secretion of steroid hormones and affects the reproduction and development of granulosa cells.

In addition, we further studied the effect of $\mathrm{GnIH}$ on granulosa cells by high-throughput sequencing. A total of 348 significant DEGs were detected, which were mainly significantly enriched in pathways such as Rap1 signaling pathway, Cytokine-cytokine receptor interaction, PI3K-Akt signaling pathway, and Ovarian steroidogenesis. Many of the significantly enriched pathways were related to the immune system and the reproductive and endocrine systems. In addition, the expression of numerous genes associated with cell cycle, cell division, and DNA replication was consistent with the physiology of proliferation and development of granulosa cells (Knight and Glister, 2006; Zhu et al., 2019). These signaling pathways may control ovarian follicular and ovulation development. Both chicken and bovine follicles showed a similar expression profile in steroidogenesis adjustment in follicular development (Hatzirodos et al., 2014).

We then selected specific DEGs to validate their levels of expression. GnIH treatment led to a significant increase in IL8 gene expression and affected multiple immune-related pathways, indicating that $\mathrm{GnIH}$ is involved in the immune response in granulosa cells. Previous studies have also shown that GnIH immune reactive neurons were widely distributed in thymus, medulla and lymph nodes, thereby modulating a variety of immune functions (Wang et al., 2018). This may be achieved by regulating IL8 gene expression. In terms of reproduction regulation, the expression of FOXO6, $A P B B 1$, and GAS1 was upregulated after GnIH treatment, whereas that of $N R G 3, T O X 3, C D C A 7$, and RRAD was downregulated. GAS1 plays a role in growth suppression, and CDCA7 is involved in MYC-mediated cell transformation and apoptosis. These changes in gene expression levels indicate that $\mathrm{GnIH}$ affects the cell cycle, growth, and apoptosis of granulosa cells. Previous studies have also demonstrated that GnIH affects the cell cycle and induces cell cycle arrest at the G2/M phase in porcine ovarian granulosa cells (Wang et al., 2018). GnlH plays a regulatory role in mediating epididymal cell apoptosis and autophagy during reproduction in male rats (Wang et al., 2018). Notably, BMPs belong to the TGF-beta ligand superfamily and are key players in follicular development (Reddi and Reddi, 2009). BMP6 has been reported to affect granulosa cell proliferation (Ocon-Grove et al., 2012). Our results showed that GnIH treatment leads to an increase in the expression of $B M P 6$, suggesting that it may regulate the proliferation of granulosa cells and follicular development through the TGF- $\beta$ signaling pathway. GnIH also modulates the expression of FGF19 and RET in granulosa cells, suggesting that GnIH may be involved in regulating the apoptosis of granulosa cells and the synthesis of intracellular gonadotropins by the MAPK signaling pathway (Tamura et al., 2004). GnIH treatment also affects the expression of ESR1 and ESRRB in the process of estrogen receptor activity and steroid binding. ESRRB is specifically expressed during 
follicular development (E et al., 2019). Downregulation of ESRRB expression revealed that GnIH treatment reduces steroid hormone receptor activity. These results indicated that $\mathrm{GnIH}$ affects the reproduction and development of granulosa cells by regulating associated signaling pathways and the expression of genes.

KEGG pathway functional analysis indicated that MROH5, LOC113840576, SDR42E1, LOC113841457, STAR, and CYP19A1 were enriched in the ovarian steroidogenesis pathway. The PPI network shows that six other genes (EGR1, ESR1, ACER2, CRHR2, CYP3A4, and NR1H4) interacting with DEGs were involved in the pathways of steroid hormone biosynthesis. We found that the top interacting DEGs were CD44, ESR1, KITLG, NGFR, IL8, PTX3, CYP19A1, EGR1, and FGF19. These DEG interactions were mainly enriched in Cell growth and death, Ovarian steroidogenesis, Immune system, and Endocrine system. Overall, our data provide new insight into the role of $\mathrm{GnIH}$ in regulating the proliferation and development-related pathways of duck granulosa cells.

\section{Conclusion}

Our study showed that GnIH treatment reduced the secretion of steroid hormones and the expression of reproduction-associated genes in duck granulosa cells in a concentrationdependent manner. Transcriptome analysis of duck granulosa cells treated with $\mathrm{GnIH}(0$ and $10 \mathrm{ng} / \mathrm{mL}$ ) identified several DEGs that may be involved in immune responses, cell growth, and steroid biosynthesis pathways. We identified four novel DEGs (MROH5, LOC113840576, SDR42E1, LOC113841457) that play important roles in the regulation of the steroid synthesis pathway. This study provided new insight into the inhibitory effects of GnIH on steroid synthesis in duck granulosa cells and identified several genes that may be involved in this process. More generally, the results of this study improve our understanding of the molecular mechanisms underlying duck reproduction.

\section{Acknowledgements}

This research was supported by the National Key Technologies R\&D Program of China (2016YFD0500510 and 2018YEF0128200) and the Pearl River S\&T Nova Program of Guangzhou (201906010040). We thank Guangdong Province Key Laboratory of Waterfowl Healthy Breeding, Guangdong Guangzhou, 510225, China for their support.

\section{References}

Anders S, Pyl PT, Huber W. HTSeq--a Python framework to work with high-throughput sequencing data. Bioinformatics. 2015;31(2):166-9. http://dx.doi.org/10.1093/bioinformatics/btu638. PMid:25260700.

Anjum S, Krishna A, Sridaran R, Tsutsui K. Localization of gonadotropin-releasing hormone (GnRH), gonadotropin-inhibitory hormone $(\mathrm{GnIH})$, kisspeptin and $\mathrm{GnRH}$ receptor and their possible roles in testicular activities from birth to senescence in mice. J Exp Zool A Ecol Genet Physiol. 2012;317:630644. http://dx.doi.org/10.1002/jez.1765. PMid: 23027641.

Bentley GE, Tsutsui K, Kriegsfeld LJ. Recent studies of gonadotropin-inhibitory hormone $(\mathrm{GnIH})$ in the mammalian hypothalamus, pituitary and gonads. Brain Res. 2010;1364:62-71. http://dx.doi.org/10.1016/j.brainres.2010.10.001. PMid:20934414.

Bentley GE, Ubuka T, McGuire NL, Chowdhury VS, Morita Y, Yano T, Hasunuma I, Binns M, Wingfield JC, Tsutsui K. Gonadotropin-inhibitory hormone and its receptor in the avian reproductive system. Gen Comp Endocrinol. 2008;156(1):34-43. http://dx.doi.org/10.1016/j.ygcen.2007.10.003. PMid:18031743.

Bolger AM, Lohse M, Usadel B. Trimmomatic: a flexible trimmer for Illumina sequence data. Bioinformatics. 2014;30(15):2114-20. http://dx.doi.org/10.1093/bioinformatics/btu170. PMid:24695404.

Ciccone NA, Dunn IC, Boswell T, Tsutsui K, Ubuka T, Ukena K, Sharp PJ. Gonadotrophin inhibitory hormone depresses gonadotrophin alpha and Follicle-Stimulating Hormone beta Subunit Expression in the pituitary of the domestic chicken. J Neuroendocrinol. 2004;16(12):999-1006. http://dx.doi.org/10.1111/j.1365-2826.2005.01260.x. PMid:15667455. 
Guo Y, Zhang G, Yao X-L, Tong R, Cheng C-Y, Zhang T-T, Wang S-T, Yang H, Wang F. Effects of nitric oxide on steroidogenesis and apoptosis in goat luteinized granulosa cells. Theriogenology. 2019;126:55-62. http://dx.doi.org/10.1016/j.theriogenology.2018.12.007. PMid:30530158.

Hatzirodos N, Irving-Rodgers HF, Hummitzsch K, Harland ML, Morris SE, Rodgers RJ. Transcriptome profiling of granulosa cells of bovine ovarian follicles during growth from small to large antral sizes. BMC Genomics. 2014;15:24. http://dx.doi.org/10.1186/1471-2164-15-24. PMid:24422759.

Huang Y, Li Y, Burt DW, Chen H, Zhang H, Qian W, Kim H, Gan S, Zhao Y, Li J, Yi K, Feng H, Zhu P, Li B, Liu Q, Fairley S, Magor K, Du Z, Hu X, Goodman L, Tafer H, Vignal A, Lee T, Kim K-W, Sheng Z, An Y, Searle S, Herrero J, Groenen MAM, Crooijmans RPMA, Faraut T, Cai Q, Webster RG, Aldridge JR, Warren WC, Bartschat S, Kehr S, Marz M, Stadler PF, Smith J, Kraus RHS, Zhao Y, Ren L, Fei J, Morisson M, Kaiser P, Griffin DK, Rao M, Pitel F, Wang J, Li N. The duck genome and transcriptome provide insight into an avian influenza virus reservoir species. Nat Genet. 2013;45(7):776-83. http://dx.doi.org/10.1038/ng.2657. PMid:23749191.

Johnson, PA. Inhibin in the hen. Poult Sci. 1993;72:955-8. http://dx.doi.org/10.3382/ps.0720955.

Kim D, Langmead B, Salzberg SL. HISAT: a fast spliced aligner with low memory requirements. Nat Methods. 2015a;12(4):357-60. http://dx.doi.org/10.1038/nmeth.3317. PMid:25751142.

Kim JS, Brownjohn PW, Dyer BS, Beltramo M, Walker CS, Hay DL, Painter GF, Tyndall JDA, Anderson GM. Anxiogenic and stressor effects of the hypothalamic neuropeptide RFRP-3 are overcome by the NPFFR antagonist GJ14. Endocrinology. 2015b;156(11):4152-62. http://dx.doi.org/10.1210/en.20151532. PMid:26259035.

Knight PG, Glister C. TGF-beta superfamily members and ovarian follicle development. Reproduction. 2006;132:191-206. http://dx.doi.org/10.1530/rep.1.01074.

Li H, Handsaker B, Wysoker A, Fennell T, Ruan J, Homer N, Marth G, Abecasis G, Durbin R, and the 1000 Genome Project Data Processing Subgroup. The sequence alignment/map format and SAMtools. Bioinformatics. 2009;25(16):2078-9. http://dx.doi.org/10.1093/bioinformatics/btp352. PMid:19505943.

Li X, Su J, Fang R, Zheng L, Lei R, Wang X, Lei Z, Jin M, Jiao Y, Hou Y, Guo T, Ma Z. The effects of RFRP-3, the mammalian ortholog of $\mathrm{GnlH}$, on the female pig reproductive axis in vitro. Mol Cell Endocrinol. 2013;372(1-2):65-72. http://dx.doi.org/10.1016/j.mce.2013.03.015. PMid:23541949.

Livak KJ, Schmittgen TD. Analysis of relative gene expression data using real-time quantitative PCR and the 2(-Delta Delta C(T)). Method. Methods. 2001;25(4):402-8. http://dx.doi.org/10.1006/meth.2001.1262. PMid:11846609.

Lovell TM, Gladwell RT, Groome NP, Knight PG. Ovarian follicle development in the laying hen is accompanied by divergent changes in inhibin $A$, inhibin $B$, activin $A$ and follistatin production in granulosa and theca layers. J Endocrinol. 2003;177(1):45-55. http://dx.doi.org/10.1677/joe.0.1770045. PMid:12697036.

Maddineni SR, Ocón-Grove OM, Krzysik-Walker SM, Hendricks GL 3rd, Ramachandran R. Gonadotropininhibitory hormone $(\mathrm{GnIH})$ receptor gene is expressed in the chicken ovary: potential role of GnIH in follicular maturation. Reproduction. 2008;135(2):267-74. http://dx.doi.org/10.1530/REP-07-0369. PMid:18239054.

McGuire NL, Kangas K, Bentley GE. Effects of melatonin on peripheral reproductive function: regulation of testicular GnIH and testosterone. Endocrinology. 2011;152:3461-70. http://dx.doi.org/10.1210/en.2011-1053.

McNatty KP, Fidler AE, Juengel JL, Quirke LD, Smith PR, Heath DA, Lundy T, O'Connell A, Tisdall DJ. Growth and paracrine factors regulating follicular formation and cellular function. Mol Cell Endocrinol. 2000;163(1-2):11-20. http://dx.doi.org/10.1016/S0303-7207(99)00235-X. PMid:10963868.

Mosa A, Neunzig J, Gerber A, Zapp J, Hannemann F, Pilak P, Bernhardt R. 2beta- and 16beta-hydroxylase activity of CYP11A1 and direct stimulatory effect of estrogens on pregnenolone formation. J Steroid Biochem Mol Biol. 2015;150:1-10. http://dx.doi.org/10.1016/j.jsbmb.2015.02.014. PMid:25746800.

Ocon-Grove OM, Poole DH, Johnson AL. Bone morphogenetic protein 6 promotes FSH receptor and antiMullerian hormone mRNA expression in granulosa cells from hen prehierarchal follicles. Reproduction. 2012;143(6):825-33. http://dx.doi.org/10.1530/REP-11-0271. PMid:22495888.

Payne $\mathrm{AH}$, Hales DB. Overview of steroidogenic enzymes in the pathway from cholesterol to active steroid hormones. Endocr Rev. 2004;25(6):947-70. http://dx.doi.org/10.1210/er.2003-0030. PMid:15583024. 
Reddi AH, Reddi A. Bone morphogenetic proteins (BMPs): from morphogens to metabologens. Cytokine Growth Factor Rev. 2009;20(5-6):341-2. http://dx.doi.org/10.1016/j.cytogfr.2009.10.015. PMid:19900831.

Roberts A, Trapnell C, Donaghey J, Rinn JL, Pachter L. Improving RNA-Seq expression estimates by correcting for fragment bias. Genome Biol. 2011;12(3):R22. http://dx.doi.org/10.1186/gb-2011-12-3r22. PMid:21410973.

Shimizu T, Ohshima I, Ozawa M, Takahashi S, Tajima A, Shiota M, Miyazaki H, Kanai Y. Heat stress diminishes gonadotropin receptor expression and enhances susceptibility to apoptosis of rat granulosa cells. Reproduction. 2005;129:463-72. http://dx.doi.org/10.1530/rep.1.00502.

Singh P, Krishna A, Tsutsui K. Effects of gonadotropin-inhibitory hormone on folliculogenesis and steroidogenesis of cyclic mice. Fertil Steril. 2011a;95(4):1397-404. http://dx.doi.org/10.1016/j.fertnstert.2010.03.052. PMid:20452585.

Singh P, Krishna A, Sridaran R, Tsutsui K. Immunohistochemical localization of GnRH and RFamiderelated peptide-3 in the ovaries of mice during the estrous cycle. J Mol Histol. 2011 b;42(5):371-81. http://dx.doi.org/10.1007/s10735-011-9340-8. PMid:21769536.

Tamura M, Nakagawa Y, Shimizu H, Yamada N, Miyano T, Miyazaki H. Cellular functions of mitogenactivated protein kinases and protein tyrosine phosphatases in ovarian granulosa cells. J Reprod Dev. 2004;50(1):47-55. http://dx.doi.org/10.1262/jrd.50.47. PMid:15007201.

Tarazona S, Garcia-Alcalde F, Dopazo J, Ferrer A, Conesa A. Differential expression in RNA-seq: a matter of depth. Genome Res. 2011;21(12):2213-23. http://dx.doi.org/10.1101/gr.124321.111. PMid:21903743.

Tsutsui K, Saigoh E, Ukena K, Teranishi H, Fujisawa Y, Kikuchi M, Ishii S, Sharp PJ. A novel avian hypothalamic peptide inhibiting gonadotropin release. Biochem Biophys Res Commun. 2000;275(2):661-7. http://dx.doi.org/10.1006/bbrc.2000.3350. PMid:10964719.

Ubuka T, Son YL, Tobari Y, Tsutsui K. Gonadotropin-inhibitory hormone action in the brain and pituitary. Front Endocrinol. 2012;3:148. http://dx.doi.org/10.3389/fendo.2012.00148. PMid:23233850.

Ubuka T, Son YL, Bentley GE, Millar RP, Tsutsui K. Gonadotropin-inhibitory hormone $(\mathrm{GnIH})$, GnIH receptor and cell signaling. Gen Comp Endocrinol. 2013;190:10-7. http://dx.doi.org/10.1016/j.ygcen.2013.02.030. PMid:23499786.

Ubuka T, Son YL, Tsutsui K. Molecular, cellular, morphological, physiological and behavioral aspects of gonadotropin-inhibitory hormone. Gen Comp Endocrinol. 2016;227:27-50. http://dx.doi.org/10.1016/j.ygcen.2015.09.009. PMid:26409890.

Wang X, Li X, Hu C. RFRP-3, the mammalian ortholog of GnIH, induces cell cycle arrest at G2/M in porcine ovarian granulosa cells. Peptides. 2018;101:106-11. http://dx.doi.org/10.1016/j.peptides.2018.01.006 PMid:29337271.

Xie C, Mao X, Huang J, Ding Y, Wu J, Dong S, Kong L, Gao G, Li C-Y, Wei L. KOBAS 2.0: a web server for annotation and identification of enriched pathways and diseases. Nucleic Acids Res. 2011;39(Suppl. 2):W316-22. http://dx.doi.org/10.1093/nar/gkr483. PMid:21715386.

Yin H, Ukena K, Ubuka T, Tsutsui K. A novel G protein-coupled receptor for gonadotropin-inhibitory hormone in the Japanese quail (Coturnix japonica): identification, expression and binding activity. J Endocrinol. 2005;184(1):257-66. http://dx.doi.org/10.1677/joe.1.05926. PMid:15642802.

Young MD, Wakefield MJ, Smyth GK, Oshlack A. Gene ontology analysis for RNA-seq: accounting for selection bias. Genome Biol. 2010;11(2):R14. http://dx.doi.org/10.1186/gb-2010-11-2-r14. PMid:20132535.

Zhu G, Fang C, Li J, Mo C, Wang Y, Li J. Transcriptomic diversification of granulosa cells during follicular development in chicken. Sci Rep-Uk. 2019;9. http://dx.doi.org/10.1038/s41598-019-41132-1.

\section{Author contributions}

SJC: Methodology, Writing-original draft; WJL: Conceptualization; CY: Data curation; XJL: Writing-original draft, review \& editing; XS: Methodology; DLJ: Project administration; YMH: Conceptualization, Funding acquisition; YBT: Writing-review \& editing. 